\title{
針葉樹材のアルカリ蒸解における炭水化物収率とへキセンウロン酸生成の挙動
}

筑波大学大学院 生命環境科学研究科 高橋史帆, 金 光范*，中川明子，大井 洋 東京大学大学院 農学生命科学研究科 横山朝哉

三菱製紙株式会社 八戸工場 古井正美

\section{Behaviors of Carbohydrate Yield and Hexenuronic Acid Formation during Softwoods Alkaline Cooking}

Shiho Takahashi, Guangfan Jin**, Akiko Nakagawa-izumi and Hiroshi Ohi Graduate School of Life and Environmental Sciences, University of Tsukuba

Tomoya Yokoyama

Graduate School of Agricultural and Life Sciences, The University of Tokyo

\section{Masami Furui}

Hachinohe Mill, Mitsubishi Paper Mills, Ltd.

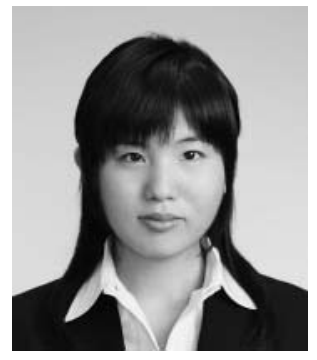

高橋史帆

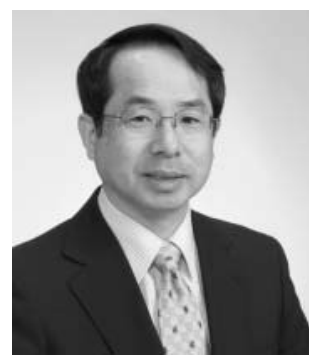

大井 洋

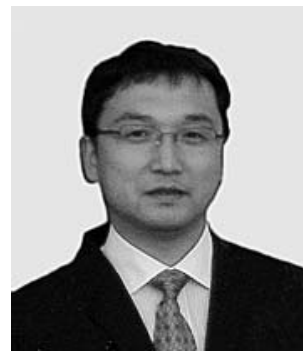

金 光范

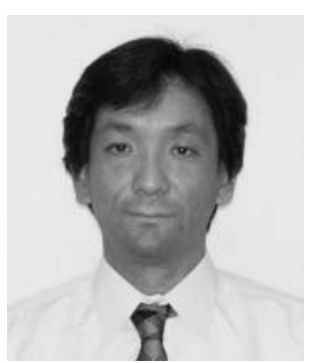

横山朝哉

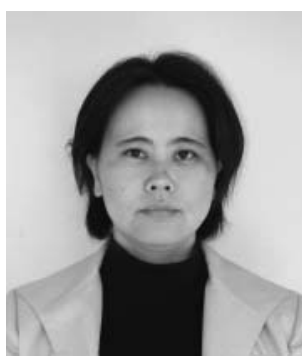

中川明子

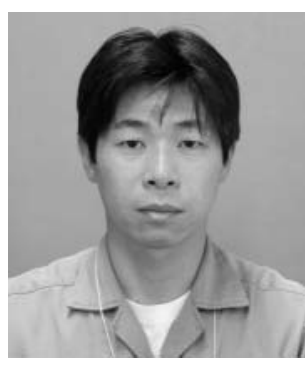

古井正美

\begin{abstract}
It is required to use more Japanese softwoods, for example, Larix leptolepis (Japanese larch), Pinus densiflora (Japanese red pine), and Cryptomeria japonica (Japanese cedar) for the effective production of pulp and bio-energy. The pulp yield in cooking stage is one of the most important factors at a pulp mill. However, it is difficult to know the yield due to a continuous operation of the mill. In this paper, we proposed on a method for estimating Japanese softwood pulp yields at a continuously operated kraft pulp mill. The behaviors of xylan, mannan, carbohydrate and hexenuronic acid (HexA) contents in various alkaline cooking of Japanese larch were studied. A part of dissolved xylan was re-adsorbed by wood fibers in the cooking, and the result indicates that the pulp yield can not be estimated from ratios of xylose to glucose $(\mathrm{X} / \mathrm{G}$ ratios) liberated by acid hydrolysis from the pulps. Therefore, we made some equations which could simulate the behaviors of delignification, carbohydrates, ratio of mannose to glucose $(\mathrm{M} / \mathrm{G}$ ratios), and HexA in the cooking from the results of kraft, kraft-AQ and PS-AQ cooks. From these equations, we clarified the relationship between pulp yields and the $\mathrm{M} / \mathrm{G}$ ratios, and then, it was shown that a good correlation existed between pulp yields and $\mathrm{M} / \mathrm{G}$ ratios at kappa number 25 . The softwoods pulp yields with kappa number 25 at the mill using the Japanese red pine and Japanese cedar mixed wood chips were estimated by the proposed method. The $\mathrm{M} / \mathrm{G}$ ratios of mill pulps from kraft- $\mathrm{AQ}$ and kraft cooks were
\end{abstract}

*現所属：浙江科技学院 軽工学院

**Present Organization : School of Light Industry, Zhejiang University of Science and Technology 
0.0812 and 0.0704 , respectively, and the result means that the pulp yield by kraft-AQ cook was $1.3 \%$ higher than that by kraft method. HexA contents of PS-AQ and kraft-AQ pulps with kappa number 25 at a given $\mathrm{H}^{-}$ factor from Japanese softwoods were higher than that of kraft pulp. At the mill trial, the HexA content of kraftAQ pulp was $7 \mathrm{mmol} / \mathrm{kg}$ higher than that of kraft pulp.

Keywords : kraft, anthraquinone, polysulfide, pulp yield, carbohydrate, hexenuronic acid 分類： $\mathrm{F}_{2} \mathrm{KP}$ 蒸解, $\mathrm{W}_{1}$ 蒸解薬品

\section{1. 緒言}

日本の森林率は $67 \%$ であり，2005 年における日本の森 林蓄積は約 40 億 $\mathrm{m}^{3}\left(162 \mathrm{~m}^{3} / \mathrm{ha}\right)$ である。森林の約 $42 \%$ は人工林である。人工林の森林蓄積は約 24 億 $\mathrm{m}^{3}$ であり, 針葉樹がその $98 \%$ を占めている ${ }^{1)}$ 。針葉樹の人工林齢級別 蓄積をみると，9 齢級（林齢が $40 〜 45$ 年生）の蓄積が全 齢級のうち最も多い2)。これらは今後主伐期に到達し, 国 産針葉樹材の供給量が増大することが予測される。しかし， 約 730 万 ha におよぶ国有林における針葉樹の成長量 (2006 年) は 1,555 万 $\mathrm{m}^{3} /$ 年であり, 我が国の木材自給率 は $20 \%$ 前後を推移している。

京都議定書では, 温室効果ガス排出量について 1990 年 を基準年として 2010 年までに基準年排出量の $6 \%$ を削減 することを目標とし，その約 3 分の 2 にあたる $3.9 \%$ を森 林による吸収量で確保することが定められた。国産材需要 の低迷と森林経営における生産性の低さなどの問題がある ために, 人工林は放置されて荒廃している。京都議定書に おいて温室効果ガス削減の算出を認められた森林は, 適切 な森林施業が行われているものと限定されている。地球温 暖化防止のためにも人工林の間伐等, 森林の適切な管理と 保全が急務となっている ${ }^{3)}$ 。

パルプ用材として植林されている広葉樹材と比較すると, 国産針葉樹材の蒸解後パルプ収率は低いが，そのため原料 $1 \mathrm{~kg}$ から黒液として得られるバイオエネルギーは大きい。 したがって，パルプ原料として国産針葉樹材の利用を拡大 することは，国内バイオエネルギー生産にとっても大きな 意義がある。

以上のことから，木材の工業的利用の過半を占めるパル プ産業においても国産針葉樹材の利用を拡大する意義は大 きい。木材資源を有効に利用するために，パルプ製造工程 において収率を正確に評価することが重要である。通常, 蒸解工程では連続操業を行うため, 蒸解におけるパルプ収 率の測定が困難である。国産針葉樹材をパルプ原料とする 場合，製材工場からの端材などの混合材チップを使用する ことが多い。そのため, 由来が既知の単一樹種の木材チッ プを使う場合よりも，パルプ品質および収率の予測がより 困難となる。これらのことから，特に国産針葉樹材を原料 とする場合, 蒸解におけるパルプ収率の正確な評価方法の 開発が求められている。一方, アルカリ蒸解ではキシラン 側鎖に結合する 4-O-methyl- $\alpha-{ }^{-}-$glucuronic acid が 4deoxyhex-4-enouronic acid (HexA) へと変化し, 蒸解条 件はパルプ中の HexA 量に影響を与える)。ブナクラフト
パルプはアカマツクラフトパルプよりキシラン含有量が

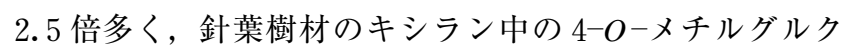
ロン酸基の頻度は広葉樹材より 2 倍多いという報告があ $ろ^{5)}$ 。針葉樹材パルプは広葉樹材パルプより HexA 量が少 ないといわれているが, 蒸解条件によって針葉樹材でも HexA 量は異なり，たとえば pine 材クラフトパルプの場 合, カッパー価 25.9 で HexA 量が $54 \mu \mathrm{mol} / \mathrm{g}$ であるとい う報告がある ${ }^{6)}$ 。針葉樹に対しても HexA 生成について蒸 解条件の影響を調べ，蒸解で取り除ける可能性を検討する ことは意義のあることである。国産針葉樹材をパルプ原料 として利用する場合, 炭水化物の挙動と合わせてアントラ キノン（AQ）などの蒸解助剤を添加したときの HexA 酸 生成の挙動を検討する必要がある。

そこで本研究では第一に, カラマツ (Larix leptolepis), アカマツ (Pinus densiflora), およびスギ (Cryptomeria japonica）材のアルカリ蒸解中における炭水化物の挙動を明 らかにし，工場における国産針葉樹材の蒸解パルプ収率の 評価法について検討を加えた。第二に，クラフト法 (Kraft 法）とクラフト・アントラキノン法（Kraft-AQ 法）およ びポリサルファイドーアントラキノン法 (PS-AQ 法) に よる蒸解において, 蒸解助剤である $\mathrm{AQ}$ とイオウの添加 が，国産針葉樹材パルプの HexA 量に与える影響を明ら かにした。

\section{2. 実験方法}

\section{1 供与試料}

筑波大学八ヶ岳演習林から樹齢 30 年のカラマツ材 (L. leptolepis）を伐採し，実験室で辺材部および心材部に分別 した後，チップを調製した。辺材部由来チップについて， チップの平均形状が $13.2 \mathrm{~mm} \times 24.8 \mathrm{~mm} \times 2.4 \mathrm{~mm}$ (厚さ) のものを蒸解用試料とした。また，三菱製紙八戸工場で入 手した工場用アカマッ・スギ材混合チップを, 実験室でア カマツ材 (P. densiflora) とスギ材 (C. japonica) にわけた。 アカマツ材およびスギ材の混合重量比は $76: 24$ であった。 分別したアカマツあるいはスギ材チップを用いて実験室で 蒸解を行った。

2.2 実験室におけるカラマツ材の蒸解およびその条件 木材チップ（絶乾重量 $45 \mathrm{~g}$ ）を精秤し， $350 \mathrm{ml}$ 容オー トクレーブに入れ, Kraft 法, Kraft-AQ 法, ソーダ・ア ントラキノン法 (Soda-AQ 法), および, $\mathrm{PS}-\mathrm{AQ}$ 法によ って, 蒸解を行った。活性アルカリ添加率 (AA 添加率)

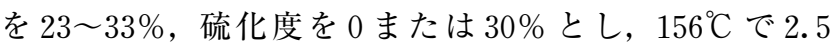
〜8.5 時間蒸解を行った。アントラキノン (AQ) 系蒸解 
助剤として，川崎化成工業製の 1,4-dihydro-9, 10-dihydroxy-anthracene sodium salt（SAQ）を用い，添加率は $0.14 \%$ とした。PS-AQ 法では, クラフト蒸解液にイオウ を加えて PS 蒸解液を調製し，イオウ添加率を $2.0 \%$ とし た。また，液比は $5.5 \mathrm{~L} / \mathrm{kg}$ とした。

\section{3 実験室におけるアカマツ・スギ材の蒸解条件}

アカマツ・スギ材それぞれについて，AA 添加率を 23 または $28 \%, \mathrm{AQ}$ 添加率を 0 または $0.14 \%$, 硫化度を $30 \%$ とし， $168^{\circ} \mathrm{C}$ で 2.5 時間の条件下で，Kraft 法，Kraft-AQ 法による蒸解を行った。

\section{4 工場実験およびその蒸解条件}

三菱製紙八戸工場において，2004 年 10 月 26,27日に Kraft および Kraft-AQ 蒸解による工場実験を行った。前 者の $\mathrm{AA}$ 添加率は $19.7 \%$, 後者は $17.0 \%$ および SAQ 添 加率 $0.1 \%$ で，硫化度は両者において 30 〜 $32 \%$ であった。 Kraft および Kraft-AQ 蒸解操業時に, それぞれパルプを 10 サンプル以上採取し，その中からカッパー価が 25 前後 のパルプを選び，分析を行った。

\section{5 パルプの構成糖分析と HexA の定量}

2.5.1 パルプの収率とカッパー価測定および中性糖分析 実験室の蒸解では, パルプから気乾シートを作成し, シ ートの絶乾重量を測定してパルプ収率を求めた。また，カ

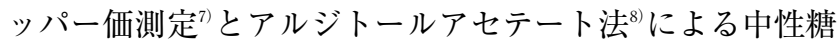
分析を行った。中性糖分析の結果から，グルコースに対す るキシロースの質量比 ( $\mathrm{X} / \mathrm{G}$ 比) およびグルコースに対 するマンノースの質量比 $(\mathrm{M} / \mathrm{G}$ 比）を求めた。工場パル プについても中性糖分析を行い， $\mathrm{M} / \mathrm{G}$ 比を求めた。

\subsection{2 パルプ中の HexA の定量分析}

HexA は酸処理に対して不安定で, 分解して 5-formyl2-furancarboxylic acid (FF) と 2-furancarboxylic acid （FA）を与える ${ }^{9,10)}$ 。パルプ中の HexAの代表的な定量法 として, 選択的酸加水分解後にUV 吸光度を用いて定量す るHUT 法がある ${ }^{9,11}$ 。本研究では, HUT 法に準じて酸加 水分解した後, 加水分解液の UV 吸収を測定する HUT 法 ではなく，高速液体クロマトグラフィー（HPLC）を用い て加水分解物を分離後に HexA を定量する方法 ${ }^{12}$ を用いた。 すなわち, パルプ絶乾重量 $0.8 \mathrm{~g}$ に $\mathrm{pH} 2.5$ のギ酸水溶液 $80 \mathrm{ml}$ を加え, オートクレーブ中で $120^{\circ} \mathrm{C}, 3$ 時間処理を した。パルプの酸加水分解溶液を $10 \mu \mathrm{l}$ 採取して HPLCで 分析し, HexA の酸加水分解生成物である FF と FA を 265 $\mathrm{nm}$ で検出して定量することにより, その合計量をHexA 量とした。

\section{3. 結果と考察}

3.1 カラマツ材のアルカリ蒸解における炭水化物の挙動 アルカリ蒸解におけるパルプ収率を評価する方法につい ては，いくつかの方法が提案されている ${ }^{13-16)}$ 。 Kleppe ${ }^{13)}$ は, 蒸解後のパルプ収率を評価する方法として, パルプ収率と カッパー価との相関を利用し，カッパー価 30〜90の針葉 樹材パルプに対して，下記(1)式を提案した。

Pulp yield $(\%)=0.14 \times$ kappa number + 定数 $\cdots \cdots(1)$

Kleppe の方法はカッパー価とパルプ収率の間の直線的
な関係から，未知のパルプ収率を評価する簡便な方法であ る。しかし，この工場では，針葉樹材の漂白用パルプの目 標カッパー価は 25 であるため漂白用パルプの収率の評価 法として Kleppe の方法を用いることはできない。さらに, 同じカッパー価のパルプでも蒸解助剤の添加の有無によっ て収率が異なることが予想され，蒸解助剤を添加したとき に得られる収率向上を評価する場合には，この方法は適切 ではないと考えられる。

Marcoccia ${ }^{14)}$ は，広葉樹材パルプ収率を評価する方法 として，パルプのグルカン含有率と粘度を用い，下記(2)式 を報告した。

Pulp yield $(\%)=$ 定数 $\mathrm{a} \times \log ($ viscosity $)$

$\div$ Glucan content $(\%)+$ 定数 b

Marcoccia らの方法は粘度とグルカン量を測定すること が必要であり, 煩雑で時間を要するのが難点であり, ポリ サルファイドや $\mathrm{AQ}$ を添加することにより得られる収率 増加の予測には適していないことが報告されている ${ }^{15)}$ 。

Easty ${ }^{16)}$ は，パルプ中の炭水化物とリグニンの含有率 によってパルプ収率を(3)式により評価する方法（炭水化物 ・リグニン法）を提案した。これは実験室で木材に対する セルロース（グルカン）収率を求め, 一方で工場パルプの 炭水化物含有量およびリグニン含有量を定量し，パルプ収 率を評価する方法である。

Pulp yield $(\%)=\mathrm{Y}_{\text {cell }} \times(\mathrm{C}+\mathrm{H}) \div \mathrm{C}+\mathrm{Y}_{\text {cell }} \times \mathrm{L} \div \mathrm{C}$ $\cdots \cdots(3)$

ここで $\mathrm{Y}_{\text {cell }}$ は絶乾チップに対するセルロース収率， $\mathrm{C}, \mathrm{H}$ およびLはそれぞれパルプのセルロース，へミセルロー スおよびリグニン含有率である。Eastyらの方法はグルカ ン収率はパルプ収率が異なっても一定の值であること，す なわち $\mathrm{Y}_{\text {cell }}$ は蒸解段階に依存せず一定であることが前提と されている。 $\mathrm{Y}_{\text {cell }}$ が一定にならない場合，収率評価の誤差 となるため針葉樹材パルプの収率評価には用いることがで きないと考えられる。

様々の蒸解条件において得られたカラマツ材パルプの構 成糖の変化を表 1 に示した。蒸解中のキシラン量の経時変 化をみると Kraft, Kraft-AQ と Soda-AQ 蒸解において, 蒸解時間が大きくなるとキシラン量が増加した。Yokoyama $ら^{8,17,18)}$ は, 広葉樹材パルプの糖分析を行い, 主要 ヘミセルロース構成糖のキシロースとセルロース構成糖の グルコースの質量比（以下 $\mathrm{X} / \mathrm{G}$ 比）を求め, 蒸解パルプ 収率との間に高い相関があることを見出した。広葉樹材は 一般に，50\% 程度のセルロースおよび 20-30\%のキシラ ンのほかに，数\%のグルコマンナンを含有している。しか し，キシラン含有量が少ない針葉樹材について Yokoyama らの方法を用いることができるか不明であった。図 1 に示 すように，カラマツ材パルプの $\mathrm{X} / \mathrm{G}$ 比とパルプ収率の関 係をみるとパルプ収率と $\mathrm{X} / \mathrm{G}$ 比の相関が低いことがわか る。これは蒸解終期に起こるキシランのパルプ繊維への再 吸着 ${ }^{19)}$ が原因の一つと考えられる。針葉樹材の場合，パル プの $\mathrm{X} / \mathrm{G}$ 比によりパルプ収率を評価することは困難であ ることが明らかとなった。

Kleppe ${ }^{20,21}$ は，工場で Kraft 蒸解にポリサルファイドを 
Table 1 Change of xylan, mannan, glucan and HexA contents of Japanese larch pulps given by kraft, kraft-AQ, PS-AQ, and soda-AQ cooks.

\begin{tabular}{|c|c|c|c|c|c|c|c|c|}
\hline $\begin{array}{l}\text { Cooking } \\
\text { method }\end{array}$ & $\begin{array}{c}\text { AA } \\
\text { charge } \\
(\%)\end{array}$ & $\begin{array}{l}\text { Cooking } \\
\text { time } \\
\text { (h) }\end{array}$ & $\begin{array}{c}\text { Xylan } \\
\text { content } \\
(\% \text { on wood })\end{array}$ & $\begin{array}{c}\text { Mannan } \\
\text { content } \\
(\% \text { on wood) }\end{array}$ & $\begin{array}{c}\text { Glucan } \\
\text { content } \\
\text { (\% on wood) }\end{array}$ & $\begin{array}{l}\text { Pulp } \\
\text { yield } \\
(\%)\end{array}$ & $\begin{array}{l}\text { Kappa } \\
\text { number }\end{array}$ & $\begin{array}{c}\text { HexA } \\
\text { content } \\
(\mu \mathrm{mol} / \mathrm{g})\end{array}$ \\
\hline Kraft-AQ & 28 & 2.5 & 0.7 & 1.9 & 18.2 & 48.7 & 39.0 & 13.6 \\
\hline Kraft-AQ & 28 & 3.5 & 0.8 & 1.7 & 18.7 & 48.5 & 29.3 & 11.1 \\
\hline Kraft-AQ & 28 & 4.5 & 0.9 & 1.3 & 17.3 & 46.1 & 23.7 & 8.1 \\
\hline Kraft-AQ & 28 & 8.5 & 0.6 & 1.2 & 14.3 & 41.3 & 11.4 & 1.3 \\
\hline Kraft-AQ & 25 & 4.5 & 0.9 & 1.6 & 16.6 & 46.0 & 27.9 & 12.3 \\
\hline Kraft-AQ & 23 & 4.5 & 1.0 & 1.6 & 17.2 & 47.2 & 34.0 & 16.1 \\
\hline Kraft-AQ & 26.5 & 4.5 & - & - & - & 45.5 & 23.3 & 9.2 \\
\hline Kraft & 28 & 4.5 & 0.8 & 1.5 & 15.7 & 44.6 & 28.0 & 8.1 \\
\hline Kraft & 28 & 5.5 & 0.7 & 1.1 & 16.1 & 44.0 & 20.5 & - \\
\hline Kraft & 28 & 8.5 & 0.9 & 1.1 & 14.2 & 41.3 & 11.4 & 1.1 \\
\hline PS-AQ & 28 & 4.5 & 1.1 & 2.2 & 17.1 & 47.5 & 23.9 & 10.6 \\
\hline PS-AQ & 23 & 4.5 & 1.0 & 2.6 & 19.0 & 50.5 & 32.2 & 20.5 \\
\hline Soda-AQ & 33 & 4.5 & 0.4 & 2.0 & 16.5 & 47.0 & 44.5 & - \\
\hline Soda-AQ & 33 & 7.5 & 0.3 & 1.5 & 15.4 & 43.8 & 26.8 & - \\
\hline Soda-AQ & 33 & 8.5 & 0.7 & 1.3 & 14.1 & 41.9 & 23.3 & - \\
\hline
\end{tabular}

Note: AQ charge and sulfur charge were $0.14 \%$ and $2.0 \%$, respectively.

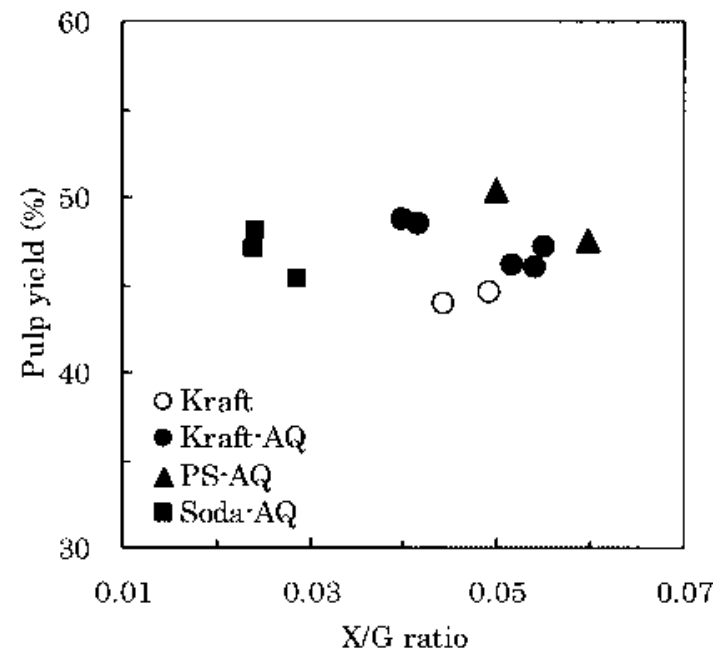

Fig. 1 Relationship between pulp yields and $\mathrm{X} / \mathrm{G}$ ratios for Japanese larch pulps with various kappa numbers given by various alkaline cooks.

添加したときの収率向上効果を把握するために，針葉樹材 パルプ中のグルコマンナン量を用いてパルプ収率を評価す る方法（グルコマンナン法）を提案した。しかし，評価の 対象パルプのカッパー価は 40-45であり，カッパー価 30 以下の漂白用パルプの場合にも，この方法が有効であるの かどうか明らかでない。また，グルコマンナン法はセルロ ース収率の向上分をパルプ収率評価に考慮していないため, 最大で $1.5 \%$ の収率誤差が生じると報告されている ${ }^{22)}$ 。一 方，針葉樹材パルプの構成糖に着目した収率評価法として

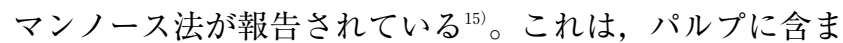
れるマンノース残基量とパルプ中の炭水化物の収率との間 の相関を利用し，工場におけるパルプ収率を予測する方法 である。Luthe ら $\left.{ }^{15}\right)$ は，ウェスタンヘムロック材 (Tsuga heterophylla）を用い, $\mathrm{AQ}$ やイオウのような蒸解助剂が添加 された場合であってもパルプ収率の予測が可能であると報 告している。

表 1 に示すように，カラマツ材のさまざまな蒸解法によ り得られたパルプ中のマンナン量の経時変化をみると, 蒸 解が進行するにつれて, マンナン量は減少した。しかし, Luthe らの結果に反してマンナン量とパルプ収率の間の相 関が低かった。そこで本研究では， $\mathrm{M} / \mathrm{G}$ 比によりパルプ 収率を評価する方法を検討した。図 2 にカラマツ材の様々 なカッパー価のパルプの収率と $\mathrm{M} / \mathrm{G}$ 比との関係を示した。 期待に反して, カッパー価が異なるパルプの場合, パルプ 収率と $\mathrm{M} / \mathrm{G}$ 比の間の相関は低かった。そこで, 以下のよ うな手順でさらに検討を加えた。

\section{2 同一カッパー価におけるパルプ収率および $\mathrm{M} / \mathrm{G}$ 比の関係}

同一カッパー価のパルプにおける収率と $\mathrm{M} / \mathrm{G}$ 比の相関 を検討するため, 図 2 のデー夕について, Kraft, Kraft$\mathrm{AQ}, \mathrm{PS}-\mathrm{AQ}$ および Soda-AQ 蒸解ごとに, カッパー価が 25 となる内挿点を求めた。これらの 4 点を図 3 に示す。 Soda-AQ 蒸解は, 工場のプロセスを考えると採用できな いため，これを除去した。

そこで, Soda $-\mathrm{AQ}$ 蒸解を除いた Kraft，Kraft-AQ，PS $-\mathrm{AQ}$ 蒸解の結果を用い, 多変量解析によりカラマッ材の 


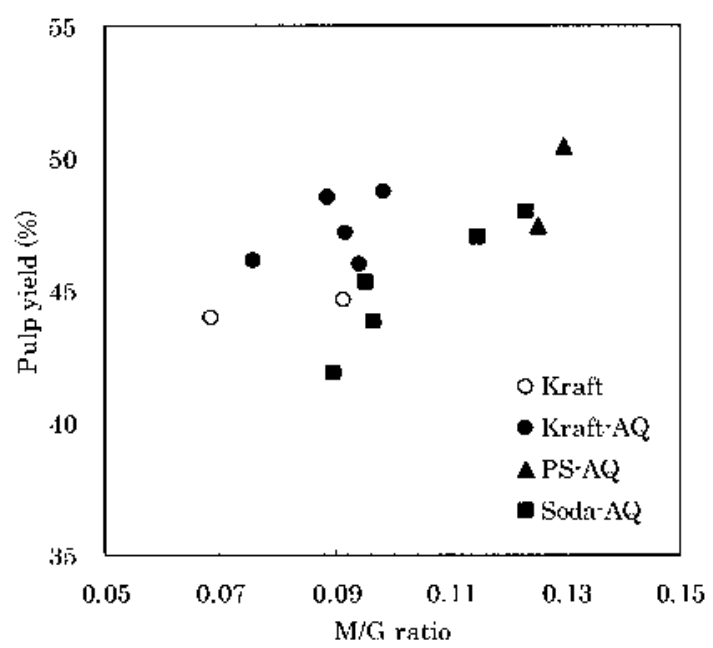

Fig. 2 Relationship between pulp yields and $M / G$ ratios for Japanese larch pulps with various kappa numbers given by various alkaline cooks.

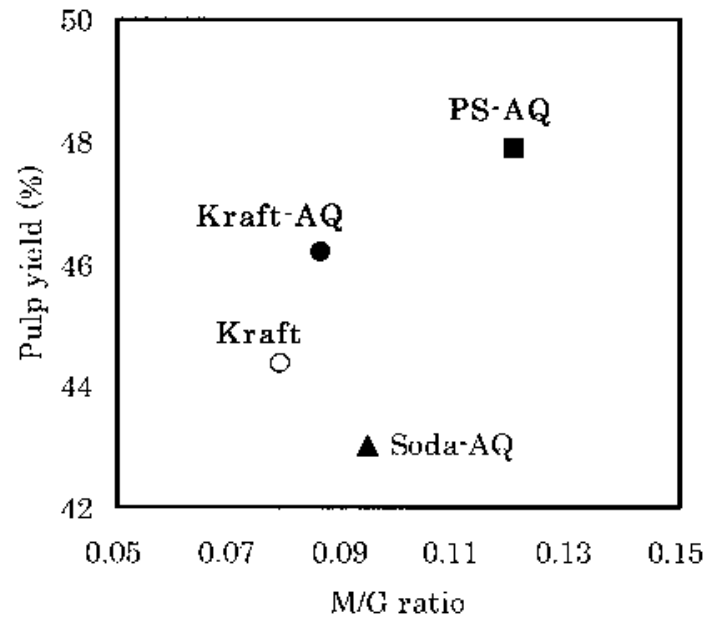

Fig. 3 Relationship between pulp yields and $\mathrm{M} / \mathrm{G}$ ratios for Japanese larch pulps with kappa number 25 given by various alkaline cooks.

アルカリ蒸解における炭水化物収率：[C]（\% on wood）, マンナン量：[M]（\% on wood), グルカン量：[G]（\% on wood), およびリグニン含有量：[L]（\% on wood）を予 測する実験式を作成した（表 2)。つぎに，この実験式か ら, H-ファクター 1155〜1605 の範囲で, 異なる AA 添加 率， $\mathrm{AQ}$ およびイオウ添加率の条件でカッパー価 25 のパ ルプを調製できる条件を選択し，それぞれの条件で 3 回繰 り返した。

すなわち, 蒸解時間 : $t(\mathrm{~h})$, 蒸解液中の水酸化物イオン 濃度：[OH] (mol/L), AQ 添加率 : $A Q （ \%$ on wood）お よびイオウ添加率：S（\% on wood）を説明変数とし, $[\mathrm{C}]$, $[\mathrm{M}] ，[\mathrm{G}]$ をそれぞれ目的変数にとった。ただし， [L] を 目的変数とする場合は $t$ ではなく $1 / t$ を説明変数とした (表 2)。表 2 の式から，カッパー価 25 となる [C] および [L] を与える蒸解条件 $([\mathrm{OH}], A Q, S)$ を決定した。 これらの蒸解条件とカッパー価とパルプ収率の関係式(4)お
Table 2 Multiple liner regression for behaviors of carbohydrates and lignin during alkaline cooks.

\begin{tabular}{c}
\hline Multiple liner regression equation \\
\hline $\ln [\mathrm{C}]=4.00-0.08[\mathrm{OH}]+0.146 A Q+0.03 S-0.03 t$ \\
$\ln [\mathrm{M}]=2.29-0.43[\mathrm{OH}]+0.204 A Q+0.19 S-0.12 t$ \\
$\ln [\mathrm{G}]=3.78-0.04[\mathrm{OH}]+0.169 A Q+0.01 S-0.02 t$ \\
$\ln [\mathrm{L}]=1.68+(-0.34[\mathrm{OH}]-0.258 A Q+0.01 S+0.21) t$ \\
\hline Legend : \\
{$[\mathrm{C}]:$ Carbohydrates yield $(\%$ on wood $)$} \\
{$[\mathrm{L}]:$ Lignin content $\%$ on wood) } \\
{$[\mathrm{M}]:$ Mannan content $(\%$ on wood) } \\
{$[\mathrm{G}]:$ Glucan content $(\%$ on wood $)$} \\
{$[\mathrm{OH}]:$ Hydroxide concentration $(\mathrm{mol} / \mathrm{L})$} \\
$A Q:$ AQ charge $(\%$ on wood) \\
$S:$ Sulfur charge $(\%$ on wood) \\
$t:$ cooking time (h)
\end{tabular}

Kappa number $=[\mathrm{L}] \div$ Pulp yield $\times 100 \div 0.13$

Pulp yield $=[\mathrm{C}]+[\mathrm{L}]$

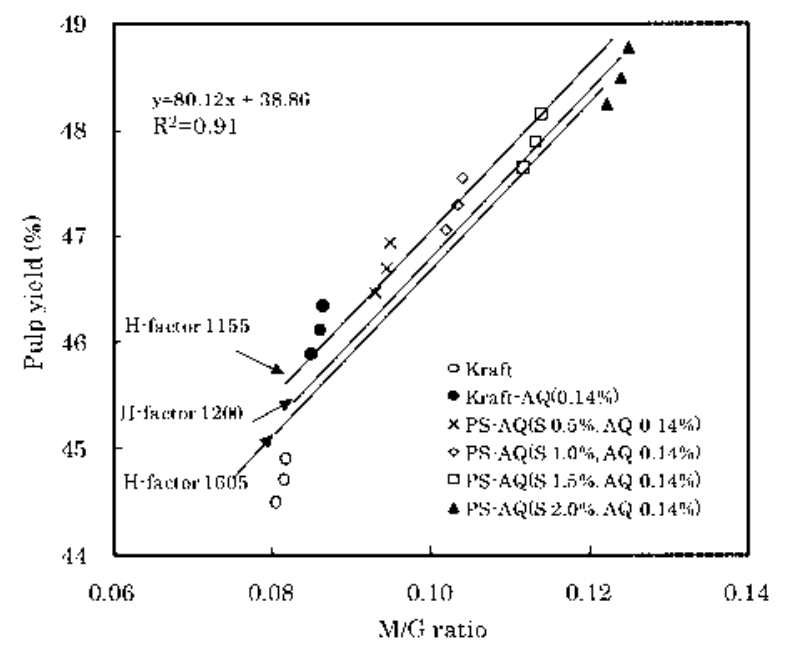

Fig. 4 Relationship between pulp yields and M/G ratios for Japanese larch pulps with kappa number 25 at H-factor 1155-1605.

よび(5)式よりカッパー価 25 における Kraft, Kraft-AQ お よび $\mathrm{PS}-\mathrm{AQ}$ 蒸解によるパルプ収率と $\mathrm{M} / \mathrm{G}$ 比を算出した。 これらのパルプの収率と $\mathrm{M} / \mathrm{G}$ 比の関係を図 4 に示した。

Kappa number $=[\mathrm{L}] \div$ Pulp yield $\times 100 \div 0.13 \cdots \cdots(4)$ Pulp yield $=[\mathrm{C}]+[\mathrm{L}] \quad \cdots \cdots(5)$

図 4 に示すように，同一カッパー価の場合，パルプ収率 と $\mathrm{M} / \mathrm{G}$ 比の間の相関は高い。このことより，あらかじめ 実験室で工場チップを蒸解し，同一カッパー価のパルプ収 率とパルプの $\mathrm{M} / \mathrm{G}$ 比の関係から収率評価のための検量線 を作成すれば，工場で採取したパルプの $\mathrm{M} / \mathrm{G}$ 比を定量す ることにより工場パルプの収率の評価が可能となることが 示された。しかし，H-ファクターが1155から 1605 の範 囲の場合，同一 $\mathrm{M} / \mathrm{G}$ 比であってもパルプ収率が約 $0.3 \%$ 


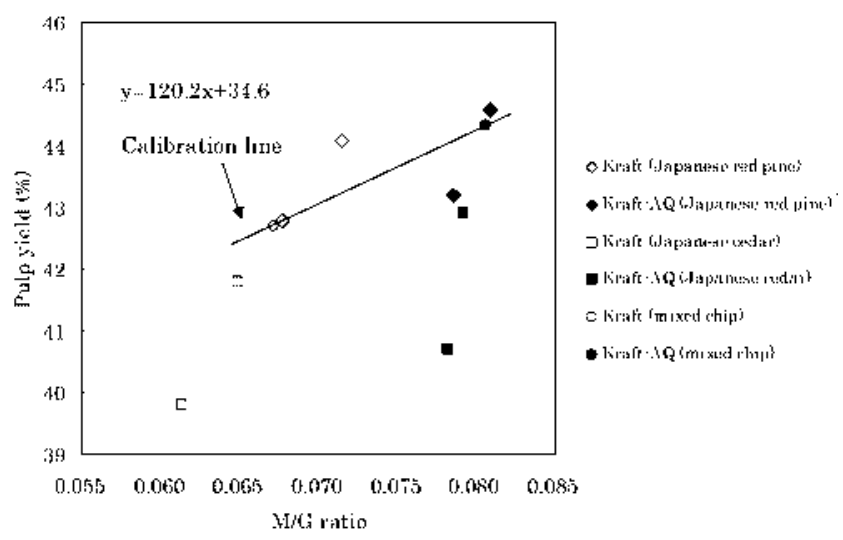

Fig. 5 Relationship between pulp yields and M/G ratios given by laboratory cooks of Japanese red pine and Japanese cedar.

異なる点には注意する必要がある。

\section{$3.3 \mathrm{M} / \mathrm{G}$ 比による工場のパルプ収率の評価}

実験室でカラマツ材を対象に $\mathrm{M} / \mathrm{G}$ 比と収率の関係を検 討し，針葉樹材パルプ収率評価の方法論を確立した。材は 異なるが，国産針葉樹材を用いている実際の工場に応用し て, 蒸解法が異なった場合の, カッパー価 25 における収 率の差を評価した。図 5 は実験室の蒸解から得られたアカ マツおよびスギパルプの $\mathrm{M} / \mathrm{G}$ 比とパルプ収率の関係を表 している。パルプのカッパー価は 20〜30の範囲にある。 ここでは, これらの結果の内挿点として, 工場チップ材の 混合比（重量比がアカマッ：スギ=76：24）でカッパー価 25 のパルプが得られると仮定した。すなわち，内挿によ って Kraft および Kraft- $\mathrm{AQ}$ 蒸解の各パルプの収率と M/ $\mathrm{G}$ 比を得て, この 2 点から検量線を作成した。検量線に用

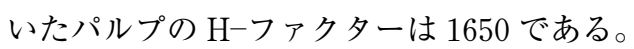

一方, 表 3 にはカッパー価 25 の工場パルプの M/G 比 を分析した結果を示した。Kraft-AQ 法が Kraft 法よりも $\mathrm{M} / \mathrm{G}$ 比が高い。カッパー価 25 のパルプの $\mathrm{M} / \mathrm{G}$ 比からパ ルプ収率を予測した結果，アカマッ・スギ混合材の Kraft - AQ 法のパルプ収率は Kraft 法より 1.3\% 高いことが示 された。

\section{4 蒸解助剂の添加が HexA 量に与える影響}

アルカリ蒸解中にキシラン側鎖に結合する $4-O-$ methyl $-\alpha-\mathrm{D}$-glucuronic acid は, メタノールの $\beta$ 脱離によって, 二重結合を有する HexAへと変化する゙。パルプ中に含ま れる HexA は, カッパー価測定で用いる過マンガン酸カ リウムあるいは漂白薬品の塩素, 二酸化塩素およびオゾン を消費することが報告されている ${ }^{4,11,23)}$ 。また，漂白後残存 したHexA はパルプ黄変（色戻り）の原因の一つと報告 されている ${ }^{24,25)}$ 。HexA 量の少ない漂白パルプを得るため には, 蒸解後にHexA 量の少ないパルプを得ることが望 ましい。

同一 $\mathrm{H}$-ファクターにおいて有効アルカリ添加率が高い 条件の場合, パルプ中の HexA が少ないことが報告され ている4”。また，同一カッパー価を得るために必要な水硫 化物イオン濃度, および, 温度が高いと, HexA 量が高い と報告されている ${ }^{26)}$ 。しかし， $\mathrm{AQ}$ およびポリサルファイ ドはパルプ収率向上の役割を担うが，これらの添加が蒸解 後のパルプ中の HexA 量にどのような影響を与えるかに 関する報告は少ない。

カラマツ材パルプの HexA 量 : [HexA] $(\mu \mathrm{mol} / \mathrm{g})$ と 蒸解条件の関係について, 多変量解析を行って下記(6)に示 す実験式を求めた。

$\ln [\mathrm{HexA}]=8.28-3.14[\mathrm{OH}]+0.247 \mathrm{AQ}$ $+0.16 S-0.44 t$

つぎにこれを用い， H-ファクター 1200 でカッパー価 25 のパルプを与える蒸解条件を求め, Kraft, Kraft- $\mathrm{AQ}$ お よび PS-AQ 蒸解によるパルプの HexA 量の算出を行った 結果を表 4 に示した。各パルプの蒸解条件㧍よび HexA 含有量は表 1 に示した。カッパー価 25 におけるパルプの HexA 量は, 3 つの蒸解法のうち PS-AQ 蒸解が最も高い 結果となった。AQ およびイオウを添加すると HexA 量を 増加させることが示された。 $\mathrm{AQ}$ を添加すると HexA 量が 高くなる原因として，同一カッパー価を得るために必要な [OH]が低いことがあげられる。PS-AQ パルプが Kraft パ ルプと比較して HexA 量が高い原因についても，同一カ ッパー価を得るために必要な $[\mathrm{OH}]$ が低いことが考えられ る。Chai ら ${ }^{27}$ は HexA 生成と分解速度に対して AQ は影 響を与えないが，AQを添加すると脱リグニンが促進され

Table 3 Estimation of Japanese red pine and Japanese cedar mixed pulp yields with kappa number 25 given kraft and kraft-AQ cooking at a mill.

\begin{tabular}{lccc}
\hline \multicolumn{1}{c}{ Cooking method } & Kappa number & $\mathrm{M} / \mathrm{G}$ ratio & $\begin{array}{c}\text { Pulp yield, } \\
\text { estimated(\%) }\end{array}$ \\
\hline Kraft & 25.2 & 0.0696 & 43.0 \\
Kraft & 24.8 & 0.0713 & 43.2 \\
Kraft-AQ & 25.2 & 0.0821 & 44.5 \\
Kraft-AQ & 24.8 & 0.0803 & 44.3 \\
\hline Kraft (average) & 25.0 & 0.0705 & 43.1 \\
Kraft-AQ (average) & 25.0 & 0.0812 & 44.4 \\
\hline
\end{tabular}


Table 4 Comparison of HexA contents between various alkali Japanese larch pulps with kappa number 25 at $\mathrm{H}$-factor 1200 .

\begin{tabular}{lccccc}
\hline $\begin{array}{c}\text { Cooking } \\
\text { method }\end{array}$ & $\begin{array}{c}\text { HexA } \\
\text { content } \\
(\mu \mathrm{mol} / \mathrm{g})\end{array}$ & $\begin{array}{c}\text { Pulp } \\
\text { yield }(\%)\end{array}$ & $\begin{array}{c}{[\mathrm{OH}]} \\
(\mathrm{mol} / \mathrm{l})\end{array}$ & $\begin{array}{c}\mathrm{AQ} \\
\text { charge } \\
(\%)\end{array}$ & $\begin{array}{c}\text { Sulfur } \\
\text { charge } \\
(\%)\end{array}$ \\
\hline Kraft & 6.3 & 44.7 & 1.46 & 0.00 & 0.0 \\
Kraft-AQ & 10.3 & 46.1 & 1.34 & 0.14 & 0.0 \\
PS-AQ & 13.6 & 48.5 & 1.36 & 0.14 & 2.0 \\
\hline
\end{tabular}

Note $: \ln [\operatorname{Hex} \mathrm{A}]=8.28-3.14[\mathrm{OH}]+0.247 \mathrm{AQ}+0.16 S-0.44 t$

Table 5 Estimation of HexA contents in Japanese red pine and Japanese cedar mixed pulp with kappa number 25 given kraft and kraft-AQ cooking at a mill.

\begin{tabular}{lcc}
\hline \multicolumn{1}{c}{ Cooking method } & Kappa number & $\begin{array}{c}\text { HexA content } \\
(\mu \mathrm{mol} / \mathrm{g})\end{array}$ \\
\hline Kraft & 25.2 & 11.2 \\
Kraft & 24.8 & 10.6 \\
Kraft-AQ & 25.2 & 18.1 \\
Kraft-AQ & 24.8 & 17.2 \\
Kraft(average) & 25.0 & 10.9 \\
Kraft-AQ (average) & 25.0 & 17.7 \\
\hline
\end{tabular}

て蒸解時間が減少するため, 同一カッパー価で比較した場 合には HexA 量が高くなると報告している。

しかし，Kraft-AQ パルプと $\mathrm{PS}-\mathrm{AQ}$ パルプを比較する と，同一カッパー価を得るために必要な[OH]は PS-AQ 蒸 解が多いにもかかわらず，パルプの HexA 量が高かった。 イオウ添加が HexA 量を大きくする影響もあることが示 唆され，この理由の解明は今後の課題である。

\section{$3.5 \mathrm{AQ}$ の添加が工場パルプの HexA 量に与える影響}

工場実験で得られたカッパー価 25 の Kraft および Kraft -AQパルプの HexA 量を表 5 に示した。 $\mathrm{AQ}$ を添加する ことにより HexA 量は $7 \mu \mathrm{mol} / \mathrm{g}$ 高い值を示した。工場実

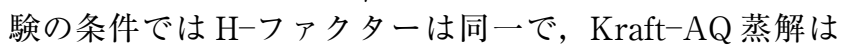
Kraft 蒸解より AA 添加率を低くしてカッパー価 25 のパ ルプを得ている。蒸解液のアルカリ量が低いと HexA 量 が多くなるので, Kraft-AQ 蒸解によるパルプの HexA 量 が高くなったと考えられる。

\section{4. 結 論}

連続操業を行っている工場で国産針葉樹材パルプ収率を 化学的に評価する方法について検討した。カラマツ材の Kraft, Kraft-AQ と Soda-AQ 蒸解の結果, キシランの再 吸着などが起こるため, パルプの $\mathrm{X} / \mathrm{G}$ 比からパルプ収率 を評価することはできないことが明らかとなった。様々な
カッパー価のパルプ収率と $\mathrm{M} / \mathrm{G}$ 比の間では相関が低かっ た。Kraft, Kraft-AQ と PS-AQ 蒸解でカッパー価 25 の パルプでは，パルプ収率と $\mathrm{M} / \mathrm{G}$ 比との相関が高いことが 明らかとなった。このことからアカマツ・スギ混合材を原 料に用いている工場パルプの $\mathrm{M} / \mathrm{G}$ 比からカッパー価 25 （当工場での目標カッパー価）のパルプ収率を評価した。 Kraft 法に AQ を添加することで収率が $1.3 \%$ 増加するこ とが示された。また，多変量解析により蒸解因子と HexA 量の関係を示す実験式を作成した結果，AQ および S の添 加はHexA 量を増加させる影響があることが示された。 同一カッパー価，同一 $\mathrm{H}-$ ファクターでは $\mathrm{PS}-\mathrm{AQ}$ 蒸解が 最も HexA 量が高いパルプを与えた。工場実験では, Kraft $-\mathrm{AQ}$ パルプの HexA 量は $\mathrm{AQ}$ を添加することで Kraft パ ルプよりも $7 \mu \mathrm{mol} / \mathrm{g}$ 高い值となった。

\section{References}

1）農林水産省統計部：農林業センサス累年統計書一林業 編一(昭和 35 年～平成 17 年)，農林統計協会， 2008

2) 林野庁編: 森林・林業統計要覧 2007 , 林野弘済 会, 2007, 10-11

3) Forestry Agency, The Ministry of Agriculture, Forestry and Fisheries of Japan: Annual Report on Trends in Forests and Forestry Fiscal Year 2005, p 142

4) Buchert J., Teleman A., Harjunpää V., Tenkanen M., Viikari L. and Vuorinen T. : Tappi J. 78 (11) 125-130 (1995)

5) Ikada T., Tomimura Y., Magara K., Ishihara M. and Hosoya S. : J. Wood Sci. 45 (5) , 417-424（1999）

6) Jiang Z. -H., Lierop B. V. and Berry R. : Tappi J. 83 (1) 167-175 (2000)

7) TAPPI TEST METHODS : “T $236 \mathrm{~cm}-85$ ”, TAPPI PRESS, 1996

8) Yokoyama T., Ohi H. and Nakamata K. JAPAN TAPPI J. 58 (6) 79-85 (2004)

9) Telman A., Harjunpää V., Tenkanen M., Buchert J., Hausalo T., Drakenberg T. and Vuorinen T. : Carbohydrate Res. 272, 55-71 (1995)

10) Telman A., Hausalo T., Tenkanen M. and Vuorinen T. : Carbohydrate Res. 280 (2), 197-208（1996) 
11) Vuorinen T., Renkanen A., Fagerström P., Buchert J. and Tenkanen M. 1996 Int. Pulp Bleaching Conf., Conf. Proceedings. TAPPI, Washington, D. C., Apr. 14 $-18,1996, \mathrm{p} 43-51$

12) Takahashi S., Nakagawa A., Jin G. and Ohi H. : Proceedings of The $52^{\text {nd }}$ Lignin Symposium, Utsunomiya, Japan, November 14-15, 2007, 110-113

13) Kleppe P. J. : Tappi J. 53 (1), 35-47 (1970)

14) Marcoccia B., Stromberg B., Progh I.R. and Kawakami C. : Japan Tappi J. 52 (4) 458-468 (1998)

15) Luthe C., Berry R. M., Radiotis T. and Nadeau L. : J. Pulp Paper Sci. 29 (11), 371-376 (2003)

16) Easty D. B. and Malcolm E. W. : Tappi J. 65 (12) 7880 (1982)

17) Ohi H., Yokoyama T., Nakamata K., Suzumi R. and Sato T. : JAPAN TAPPI J. 58 (10) 1446-1452（2004）

18) Yokoyama T. and Ohi H. : JAPAN TAPPI J. 58 (12) 1742-1751 (2004)
19) Meller A. : Holzforschung 19 (4) 118-124（1965)

20) Kleppe P. J. : Tappi J. 58 (8) 172-176 (1975)

21) Kleppe P. J. : Paperi Puu, 63 (4) 204-210 (1981)

22) Vaaler D., Eriksen O., Ribe E. and Moe S. : Seventh European Workshop on Lignocellulostics and Pulp, Conf. Proceedings. Turku, Finland, August 2629, 2002, 265-268

23) Li J. and Gellerstedt G. : Carbohydrate Res. 302, 213218 (1997)

24) Granström A., Eriksson T. and Gellerstedt G. : Nord. Pulp Paper Res. J. 16 (1) 18-23 (2001)

25) Kawae A. and Uchida Y. : Appita J. 58 (5) 378-381. (2005)

26) Gustavsson C. and Wafa AI-Dajani W. : Nord. Pulp Paper Res. J. 15 (2) 160-167 (2000)

27) Chai X. -S., Yoon S., -H., Zhu J. Y. and Li J. : J. Pulp Paper Sci. 27 (12) 407-411 (2001)

(受理：’08.7.31)

JAPAN TAPPI JOURNAL accepts scientific papers written either in Japanese or in English. We, JAPAN TAPPI, translate them into the other of the two languages (Japanese into English and English into Japanese) and print them in addition to the originals under the permission of the authors. We believe that this service of translation will help our subscribers to find and understand the scientific value of the original paper more clearly, and will contribute to the development of science and technology in the paper industry.

- Regarding figures and tables, refer to the original article in Japanese.

- The copy right of the translated version belongs to JAPAN TAPPI.

- If there is any inconsistency between the two versions, the original is always true.

- JAPAN TAPPI is not responsible to any outcomes based on the translated version.

\section{Introduction}

In Japan, $67 \%$ of the area of national land is covered with forests. The growing wood stock in Japan is about 4 billion $\mathrm{m}^{3}\left(162 \mathrm{~m}^{3} / \mathrm{ha}\right)$ in 2005 . Planted forests constitute about $42 \%$ of all the Japanese forests, and the growing wood stock of planted forests reaches about 2.4 billion $\mathrm{m}^{3}$, which are mostly consisted of softwoods $(98 \%)^{1)}$. When we focus on age of planted softwood forest, the growing wood stock in the class IX (40-45 years old) is the largest among all the classes ${ }^{2}$. It is anticipated that the forests classified in the class IX will hereafter reach the final cutting age, involving increase in domestic softwood supply. However, annual increment of softwood in Japanese national forests (7.3 million ha) is 15.55 million $\mathrm{m}^{3} /$ year for 2006 , and the self-sufficiency rate of industrial wood is maintained at about $20 \%$ in Japan.

It was decided as the target of the Kyoto Protocol that the greenhouse gas emission would be reduced by $6 \%$ of the base year (1990) by 2010 and about two thirds of this
$6 \%$ reduction $(3.9 \%)$ should be secured through the forest carbon sink. Japanese planted forests have not been managed well and devastated because of several problems, such as low domestic wood demand and low productivity of forest management. The Kyoto Protocol permits only appropriately managed forests to contribute to reduction of the greenhouse gas. Therefore, it is the urgent problem that planted forests should be appropriately managed and conserved by thinning of the forests as well as by others to prevent the global warming ${ }^{3)}$.

Pulp yield after cooking of domestic softwoods is lower than that of hardwoods planted as raw materials of pulp, which alternatively accompanies larger bio-energy production from softwoods black liquor that is obtained from $1 \mathrm{~kg}$ of original wood. Therefore, it is very important to promote utilization of domestic softwoods as raw materials of pulp, aiming at producing larger bio-energy.

On the basis of these backgrounds, it is significant to expand utilization of domestic softwoods in pulp and paper industry, which occupies the majority of industrial wood 
consumption. For efficient utilization of wood resources, it is required to accurately estimate pulp yield during its production process. It is generally difficult to estimate pulp yield in cooking process because of continuous operation of the process. When domestic softwoods are utilized as raw materials of pulp, it is common to use mixed wood chips, parts of which are discharged as residues from sawmills. Because of this, the estimation of pulp yield and quality is more difficult than when raw material woods are constituted only from a wood species whose origin is clearly known. It is necessary to develop a method for the accurate estimation of pulp yield in continuous cooking process especially when domestic softwoods are utilized as raw materials.

During alkaline cooking, $4-O-$ methyl- $\alpha-\mathrm{D}^{-}$glucuronic acid groups linked to xylan are converted into 4-deoxyhex -4-enuronic acid (HexA) groups, and cooking conditions affect HexA content of pulp ${ }^{4}$. It has been reported that the xylan content in beech kraft pulp was 2.5 times higher than that in red pine kraft pulp, and that the amount of $4-$ $O-$ methyl $-\alpha-\mathrm{D}^{-}$-glucuronic acid in softwood xylan is about twice of that in hardwood xylan ${ }^{5}$. It is believed that softwood pulp contains smaller amount of HexA than hardwood pulp. However, HexA content of softwood pulp varies depending on cooking conditions, and it has been reported, for example, that the amount of HexA in pine kraft pulp is $54 \mu \mathrm{mol} / \mathrm{g}$ when the kappa number is $25.9^{6)}$. It is significant to examine the effect of cooking conditions on the HexA formation and the possibility of the HexA removal during cooking of softwoods. When domestic softwoods are used as raw materials of pulp, it is required to examine the formation of HexA as well as the behavior of carbohydrates in cooking with an additive, such as anthraquinone $(\mathrm{AQ})$.

In this study, we clarified the behavior of carbohydrates during alkaline cooking of Japanese softwoods, larch (Larix leptolepis), red pine (Pinus densiflora), and cedar (Cryptomeria japonica), and developed a method for the accurate estimation of domestic softwood pulp yield at a continuous cooking mill. We also evaluated the effect of adding AQ and elemental sulfur as cooking additives on the amount of HexA in domestic softwood pulps obtained by Kraft, Kraft -anthraquinone (Kraft-AQ), and polysulfide-anthraquinone (PS-AQ) methods.

\section{Materials and methods}

\section{1 Materials}

Japanese larch (L. leptolepis) was obtained from the Agricultural and Forestry Research Center of University of Tsukuba, Yatsugatake forest (Kawakami, Nagano, Japan), which has been grown for thirty years. The larch wood was divided into sapwood and heartwood portions in our laboratory (at University of Tsukuba), and two kinds of wood chips were prepared from each portion. The average size applied to cooking experiments was $13.2 \mathrm{~mm} \times$ $24.8 \mathrm{~mm} \times 2.4 \mathrm{~mm}$ in sapwood chips.

Industrial softwood chips, which were consisted of Japanese red pine ( $P$. densiflora) and Japanese cedar ( $C$. japonica), were obtained from Hachinohe Mill, Mitsubishi Paper Mills, Ltd. (Aomori, Japan), and divided into each wood species by hand in our laboratory. The weight ratio of red pine to cedar was 76 to 24 . Wood chips of each species were individually subjected to cooking experiments in our laboratory.

2.2 Method and conditions for laboratory cooking of Japanese larch

Into a $350 \mathrm{ml}$ stainless steal autoclave, $45 \mathrm{~g}$ (oven-dry base) of Japanese larch chips were put, and cooked by Kraft, Kraft-AQ, Soda-AQ, or PS-AQ method. Cooking conditions were as follows: active alkali charge (AA charge) $23-33 \%$, sulfidity 0 or $30 \%$, maximum temperature $156^{\circ} \mathrm{C}$, total time $2.5^{-8.5} \mathrm{~h}$. A cooking additive of $\mathrm{AQ}$ type, 1, 4-dihydro-9, 10-dihydroxyanthracene sodium salt (SAQ), was provided by Kawasaki Chemicals Ltd. (Kanagawa, Japan), and used with $0.14 \%$ charge. In PS-AQ method, cooking liquor was prepared by the addition of elemental sulfur into white liquor with $2 \%$ charge. The ratio of liquor to wood was adjusted to $5.5 \mathrm{l} / \mathrm{kg}$.

2.3 Method and conditions for laboratory cooking of Japanese red pine and cedar

Japanese red pine and cedar chips were individually cooked by Kraft or Kraft-AQ method under following conditions : AA charge 23 or $28 \%$, AQ charge 0 or $0.14 \%$, sulfidity $30 \%$, maximum temperature $168^{\circ} \mathrm{C}$, total time $2.5 \mathrm{~h}$.

2.4 Description of mill trial and conditions of mill cooking

A mill trial was conducted at Hachinohe Mill, Mitsubishi Paper Mills, Ltd. on October 26-27 th, 2004. Kraft and Kraft-AQ methods were applied to the mill trial. Conditions were as follows: AA charge $19.7 \%$, sulfidity 30 $32 \%$ in Kraft method, AA charge $17.0 \%$, SAQ charge $0.1 \%$, sulfidity $30-32 \%$ in Kraft-AQ method. More than 10 pulp samples were collected during each cooking method, and pulps with kappa number around 25 were chosen from these samples and subjected to chemical analyses.

2.5 Analysis of carbohydrate composition and determination of HexA content of pulp

2.5.1 Analysis of yield, kappa number, and neutral sugar composition of pulp

Hand sheets were prepared from pulps obtained by the laboratory cookings, and the pulp yields were determined by measuring their oven-dried weights. Kappa numbers of the pulps were determined using the hand sheets, according to TAPPI test method ${ }^{7}$. Neutral sugar composi- 
tions of the pulps were analyzed by the alditol acetate $\operatorname{method}^{8)}$. The weight ratios of xylose to glucose (X/G ratio) and of mannose to glucose ( $\mathrm{M} / \mathrm{G}$ ratio) in the hydrolyzates of the acid hydrolysis of the pulps were determined using the results of the neutral sugar compositions. The $\mathrm{M} / \mathrm{G}$ ratios were also determined for pulps obtained at the mill trial.

\subsubsection{Analysis of HexA content of pulp}

HexA is readily hydrolyzed and converted into 5-formyl -2-furancarboxylic acid (FF) or 2-furancarboxylic acid (FA) under acidic conditions ${ }^{9), 10)}$. One of the representative methods for the determination of HexA content of pulp is the HUT method in which HexA is determined by UV absorbance of the hydrolyzate obtained by the selective hydrolysis under the acidic conditions ${ }^{9), 11}$. We applied an acidic hydrolysis similar to the selective hydrolysis in the HUT method to this study. After the hydrolysis, the hydrolyzate was subjected to high performance liquid chromatography (HPLC), and FF and FA were separately quantified using a UV detector ${ }^{12}$. That is, $0.8 \mathrm{~g}$ of ovendried pulp was quantitatively treated with $80 \mathrm{ml}$ of an aqueous solution of formic acid ( $\mathrm{pH} 2.5)$ at $120^{\circ} \mathrm{C}$ for $3 \mathrm{~h}$ in an autoclave. Then, $10 \mu \mathrm{l}$ of the reaction solution was directly injected to HPLC and the amounts of FF and FA were quantified using the absorbance at $265 \mathrm{~nm}$. The total amount of FF and FA was applied to the amount of HexA.

\section{Results and discussion}

\section{1 Behavior of carbohydrates during alkaline cook- ing of Japanese larch}

Several methods have been proposed for the estimation of pulp yield during alkaline cooking ${ }^{13-16}$. Kleppe has proposed the following formula (1), which is dependent on the linear correlation between pulp yields and kappa numbers of softwood pulps in the kappa number range between 30 and $90^{13)}$.

Pulp yield $(\%)=0.14 \times$ kappa number + constant $\cdots \cdot(1)$

The utilization of this correlation is a simple method to estimate unknown pulp yield. However, this method cannot be applied to the estimation of pulp yield when the target kappa number is set up to 25 for lowering loads in subsequent bleaching processes. Furthermore, it is considered that the method of Kleppe is not appropriate when the focus of attention is on the gain of pulp yield attained by the addition of cooking additives. This is because it is expected that pulp yields at a given kappa number vary depending on the presence or absence of cooking additives.

Marcoccia and $\mathrm{CO}^{-}$workers have proposed the following formula (2) as a method for the estimation of hardwood pulp yield using glucan content and viscosity of pulps ${ }^{14)}$.
Pulp yield $(\%)=\mathrm{a} \times \log ($ viscosity $)$

$\div$ Glucan content $(\%)+\mathrm{b}(\mathrm{a}, \mathrm{b}:$ constants $) \cdots \cdot(2)$

The method of Marcoccia disadvantageously requires complex and time-consuming procedures, which are the determination of viscosity and glucan content of pulp. It has been reported that this method is not appropriate for the estimation of yield gain attained by the addition of AQ and polysulfide ${ }^{15)}$.

Easty and $\mathrm{co}^{-}$workers have proposed a method (carbohydrate-lignin method) to estimate pulp yield based on carbohydrate (glucan) and lignin contents of pulp using the following formula $(3)^{16)}$.

Pulp yield $(\%)=\mathrm{Y}_{\text {cell }} \times(\mathrm{C}+\mathrm{H}) \div \mathrm{C}+\mathrm{Y}_{\text {cell }} \times \mathrm{L} \div \mathrm{C}$

$\mathrm{Y}_{\text {cell }}$ represents cellulose yield based on oven-dried wood. $\mathrm{C}, \mathrm{H}$ and $\mathrm{L}$ represent cellulose, hemicellulose and lignin contents of pulp, respectively. It is assumed in this method that glucan contents of cooked pulps are constant even when their yields are different. This indicates that $Y_{\text {cell }}$ is constant without depending on progress of cooking process. When $Y_{\text {cell }}$ varies with change in pulp yield, this method cannot be applied to the estimation of softwood pulp yield.

Table 1 shows the changes in the carbohydrate compositions of Japanese larch pulps obtained by various cooking conditions. The xylan contents of pulps cooked by Kraft, Kraft-AQ and Soda-AQ increased with the progress of the cooks. Yokoyama and co--workeres examined carbohydrate compositions of hardwood pulps to determine the weight ratios of xylose to glucose $(\mathrm{X} / \mathrm{G} \text { ratio })^{8), 17), 18)}$, which are compositions of hemicellulose and cellulose, respectively, and liberated by acid hydrolysis of the pulps. They have found that there is a good linear correlation between pulp yields and $\mathrm{X} / \mathrm{G}$ ratios. Hardwoods generally consist of a few percent of glucomannan, about $50 \%$ of cellulose and $20-30 \%$ of xylan. However, it has been unknown whether the method of Yokoyama can also be applied to the yield estimation of pulp obtained from softwood because xylan content is much lower in softwood than in hardwood. As shown in Fig. 1, the correlation between pulp yields and $\mathrm{X} / \mathrm{G}$ ratios of Japanese larch pulps prepared in this study was low. It is considered as one of the reasons of this low correlation that a part of dissolved xylan is re-adsorbed on wood fiber surface in the final stage of cooking ${ }^{19)}$. It has been proved that the estimation of pulp yield using $\mathrm{X} / \mathrm{G}$ ratio of the pulp is difficult when softwood is used as a raw material.

Kleppe has proposed a method to estimate softwood pulp yield using glucomannan content of pulp (Glucomannan method), aiming at examining the effect of adding polysulfide to mill kraft cooking on the yield gain ${ }^{20,21}$. However, it is unclear whether the Glucomannan method is 
also effective for pulps with kappa number below 30 because the target kappa number is $40-45$ in this method. Moreover, it has been reported that the yield estimation by the Glucomannan method includes errors as the maximum value to be $1.5 \%$ since this method does not take a part of the yield gain of cellulose into consideration ${ }^{22)}$. On the other hand, the Mannose method has been proposed for the estimation of pulp yield based on carbohydrate composition of softwood pulp ${ }^{15}$. This method estimates yields of softwood pulps prepared at a mill, using a correlation between carbohydrate yields and contents of mannose residues of pulps. Luthe and $\mathrm{co}^{-}$workers have reported that the Mannose method can also estimate yield of pulps obtained by cookings with addition of $\mathrm{AQ}$ and elemental sulfur, using Western hemlock (Tsuga heterophylla) $\operatorname{wood}^{15)}$.

As shown in Table 1, mannan content of pulps obtained by various alkaline cooks of Japanese larch wood decreased with the progress of the cooking processes. Contrary to the results of Luthe and co-$^{-}$workers, the correlation between yields and mannan contents of pulps was low. Thus in this study, we evaluated a method for the estimation of pulp yield using weight ratio of mannose to glucose (M/G ratio), which are obtained by acid hydrolysis of pulp. Fig. 2 shows the correlation between yields and $M / G$ ratios of Japanese larch pulps with various kappa numbers. Contrary to our expectation, the correlation was low when kappa numbers of the pulps were different. We evaluated this method further according to the procedures described in the next section.

\section{2 Correlation between yields and $M / G$ ratios of} pulps with a given kappa number

In order to examine the correlation between yields and $\mathrm{M} / \mathrm{G}$ ratios of pulps with a given kappa number, the pulp yields and $\mathrm{M} / \mathrm{G}$ ratios at kappa number 25 were calculated for each cooking method, Kraft, Kraft-AQ, PS-AQ and Soda-AQ, by the interpolation using the data shown in Fig. 2. The resulting four points are shown in Fig. 3. The data of Soda-AQ cooking was rejected since this cooking could not be applied to the mill trial due to the mill process.

Thus, we created experimental equations for the estimation of the compositions of pulps during alkaline cooking of Japanese larch wood, utilizing the data points of Kraft, Kraft-AQ and PS-AQ cooks in the multiple classification analysis. The compositions analyzed were as follows : carbohydrate yield [C] (\% on wood), mannan content $[\mathrm{M}]$ (\% on wood), glucan content $[\mathrm{G}]$ (\% on wood), and lignin content [L] (\% on wood) (Table 2). We subsequently selected the cooking parameters, AA charge, and $\mathrm{AQ}$ and sulfur charges, by which pulps with kappa number 25 could be prepared at three $\mathrm{H}$-factors, 1155, 1200 and 1605 . That is, we conducted the multiple classification analysis, using each of the following parameters, cooking time : $t(\mathrm{~h})$, hydroxide ion concentration in cooking liquor : $[\mathrm{OH}](\mathrm{mol} / \mathrm{L}), \mathrm{AQ}$ charge : $A Q$ (\% on wood) and sulfur charge : $S$ (\% on wood), as an explaining variable and each of $[\mathrm{C}],[\mathrm{M}]$ and $[\mathrm{G}]$ as an objective variable. When we used [L] as an objective variable, not $t$ but $1 / t$ was used as an explaining variable. The cooking conditions, $[\mathrm{OH}], A Q$ and $S$, were determined by the equations shown in Table 2, under which pulps with [C], [L] and kappa number 25 could be prepared. These cooking conditions and the following formulas (4) and (5), representing kappa number and pulp yield, respectively, made it possible to estimate pulp yields and $\mathrm{M} / \mathrm{G}$ ratios of pulps with kappa number 25 obtained by Kraft, Kraft-AQ and PSAQ methods. The correlation between these pulp yields and $\mathrm{M} / \mathrm{G}$ ratios is shown in Fig. 4.

Kappa number $=[\mathrm{L}] \div$ Pulp yield $\times 100 \div 0.13 \cdots \cdots(4)$

Pulp yield $=[\mathrm{C}]+[\mathrm{L}] \quad \cdots \cdots(5)$

The correlation between pulp yields and $M / G$ ratios was high when pulps with the same kappa number were evaluated, as shown in Fig. 4. It was suggested that yield of pulps prepared at a mill can be estimated by the determination of $\mathrm{M} / \mathrm{G}$ ratios of the pulps when a calibration line is created by utilizing the high correlation between yields and $\mathrm{M} / \mathrm{G}$ ratios of pulps with a given kappa number. However, it should be noted that the difference in yields of pulps obtained by cooks with the $\mathrm{H}$-factor range between 1155 and 1605 is about $0.3 \%$ even if the pulps have the same $\mathrm{M} / \mathrm{G}$ ratio.

\section{3 Estimation of yield of pulp obtained at mill trial using $\mathrm{M} / \mathrm{G}$ ratio}

We have evaluated the correlation between yields and $\mathrm{M} / \mathrm{G}$ ratios of pulps obtained from Japanese larch wood in our laboratory, and established a method for the estimation of softwood pulp yields. On the basis of this method, we estimated the difference in pulp yields when the pulps were prepared to be kappa number 25 by various cooking methods in the mill (see 2.4 for description) although not Japanese larch but Japanese red pine and cedar were used as mixed chips in the mill. Fig. 5 shows the correlations between yields and $\mathrm{M} / \mathrm{G}$ ratios of pulps obtained by the cooks of each of Japanese red pine and cedar in our laboratory. The kappa numbers of the pulps were in the range from 20 to 30 . The weight ratio of Japanese red pine to cedar in mixed chips was 76 to 24 at the mill. It was presumed that the interpolations of the data shown in Fig. 5, according to this mixed ratio, gave data points which represent pulps prepared from the cookings of wood chips mixed with the same ratio. Thus, yields and $\mathrm{M} / \mathrm{G}$ ratios of pulps were estimated by the interpolation in each of Kraft and Kraft-AQ method. Two data points obtained by the interpolations in each method (Fig. 5) were used as a cali- 
bration line for the estimation of pulp yield at the mill trial. The H-factor 1650 was applied to the creation of the calibration line.

$\mathrm{M} / \mathrm{G}$ ratios of pulps with kappa number 25 obtained from the mill trial are shown in Table 3. The $\mathrm{M} / \mathrm{G}$ ratios of the pulps cooked by Kraft-AQ method were higher than those by Kraft method. It was shown that the yield of pulps cooked by Kraft-AQ method is $1.3 \%$ higher than that by Kraft method when pulp yields are estimated from $\mathrm{M} / \mathrm{G}$ ratios of pulps with kappa number 25 .

\section{4 Effect of addition of cooking additives on HexA content}

During alkaline cooking, $4-O-$ methyl $-\alpha-\mathrm{D}^{-}$glucuronic acid groups linked to xylan are converted into HexA, which have a double bond in a molecule, by the $\beta$-elimination of methanol ${ }^{4}$. It has been reported that HexA in pulp consumes permanganate, which is used in the determination of kappa number, or some bleaching chemicals such as chlorine, chlorine dioxide and ozone ${ }^{4), 11,23)}$. HexA remaining in bleached pulps are considered to be one of the factors for yellowing of pulps (brightness reversion) ${ }^{24), 25)}$. It is required to obtain unbleached pulp with small content of HexA for preparing bleached pulp with small content of HexA.

It has been reported that high effective alkali charge leads to pulp with low HexA content at the same $\mathrm{H}$-factor $^{4}$. It has also been reported that pulps with a given kappa number but relatively high HexA contents are prepared when high concentration of hydrogen sulfide and high temperature are applied as cooking parameters ${ }^{26)}$. The addition of $\mathrm{AQ}$ and polysulfide attains the gain of pulp yield. However, there are few studies as to the effect of cooking additives on HexA content of unbleached pulp.

We determined the following experimental equation (6) for Japanese larch pulps, conducting the multiple classification analysis of the correlation between HexA content: [HexA] $(\mu \mathrm{mol} / \mathrm{g})$ and cooking conditions.

$\ln [\mathrm{HexA}]=8.28-3.14[\mathrm{OH}]+0.247 \mathrm{AQ}$

$$
+0.16 S-0.44 t
$$

By utilizing this equation, we subsequently determined cooking conditions, under which pulps with kappa number 25 were prepared at $\mathrm{H}$-factor 1200 . Based on these conditions, the HexA contents of the pulps, which were assumed to be prepared by Kraft, Kraft-AQ and PS-AQ cooking methods, could be calculated by the equation (6), and are shown in Table 4. The cooking conditions and the HexA content of each pulp are shown in Table 1.

The HexA content of the pulp obtained by PS-AQ method was the highest among three cooking methods when kappa number of the pulp was 25. It was also shown that the addition of $\mathrm{AQ}$ and elemental sulfur increased HexA content. One of the main reasons for high HexA contents in pulps obtained by cooks with the addition of AQ would be that Kraft-AQ pulps with kappa number 25 are obtained by a lower $[\mathrm{OH}]$ than Kraft pulps with the same kappa. The same reason can also be applied to the explanation of the phenomenon that the PS-AQ pulp has higher HexA content than the Kraft pulp. Chai and co- $^{-}$ workers have reported that HexA content of a pulp prepared by cooking with $\mathrm{AQ}$ is higher than that without $\mathrm{AQ}$ at a given kappa number because $\mathrm{AQ}$ shortens cooking time due to the acceleration of delignification in spite of the absence of the effect on the formation and degradation of HexA ${ }^{27)}$. However, the PS-AQ pulp had higher HexA content than the Kraft-AQ pulp at a given kappa number although $[\mathrm{OH}]$ required was higher for the preparation of the former than for the production of the latter. It was suggested that the addition of elemental sulfur may affect HexA content of pulp. This topic is further investigated in the future.

\subsection{Effect of addition of AQ on HexA content at mill trial}

The HexA contents of the mill Kraft and Kraft-AQ pulps with kappa number 25 are shown in Table 5. The addition of $\mathrm{AQ}$ increased HexA content by $7 \mu \mathrm{mol} / \mathrm{g}$. In the mill trial, Kraft-AQ method required lower AA charge than Kraft method when pulps with kappa number 25 were prepared by these methods at the same $\mathrm{H}$-factor. It is considered that the HexA contents of the mill Kraft-AQ pulps are higher than those of the mill Kraft pulps because HexA content increases with the decrease of AA charge in cooking liquor.

\section{Conclusions}

We tried to develop chemical methods for the estimation of domestic softwood pulp yield at a mill with continuous operation. Pulp yields could not be estimated by $\mathrm{X} / \mathrm{G}$ ratios of the pulps probably because of the re-adsorption of xylan on pulp surface, when Japanese larch wood was cooked by Kraft, Kraft-AQ and Soda-AQ methods as a raw material. The correlation between yields and $\mathrm{M} / \mathrm{G}$ ratios of pulps with various kappa numbers was not good. It was proved that there was a good correlation between yields and $\mathrm{M} / \mathrm{G}$ ratios of pulps with kappa number 25 obtained by Kraft, Kraft-AQ, and PS-AQ cooks. On the basis of this good correlation, pulp yields at the mill, where raw material was mixed chips of Japanese red pine and cedar, were estimated by $\mathrm{M} / \mathrm{G}$ ratios of the pulps when kappa number of the pulps was 25 (the target number of this mill). The yield gain by the addition of AQ to the Kraft method was shown to be $1.3 \%$ in the mill trial. An experimental equation was developed by the multiple classification analysis, which led to establishing the correlation between cooking conditions and HexA contents of pulps. It 
was shown that the addition of $\mathrm{AQ}$ and elemental sulfur increased HexA content of pulp. The PS-AQ method gave pulps with the highest HexA content among three cooking methods at a given kappa number and $\mathrm{H}$-factor. At the mill trial, the HexA content of the Kraft-AQ pulp was $7 \mu$ $\mathrm{mol} / \mathrm{g}$ higher than that of the Kraft pulp. The HexA content of pulps was the highest when the pulps were prepared by three cooking methods to show the same kappa number at the same $\mathrm{H}$-factor.

\section{References}

1) Ministry of Agriculture, Forestry and Fisheries Statistics department: Census of Agriculture and Forestry Ruinen tokei sho - Ringyou hen- (1960 2005), Nourintoukeikyoukai, 2008

2) Forestry Agency: Shinrin - Ringyou tokei youran 2007, Rinyakousaikai, 2007, 10-11

3) Forestry Agency, The Ministry of Agriculture, Forestry and Fisheries of Japan: Annual Report on Trends in Forests and Forestry Fiscal Year 2005, p 142

4) Buchert J., Teleman A., Harjunpää V., Tenkanen M., Viikari L. and Vuorinen T. : Tappi J. 78 (11) 125-130 (1995)

5) Ikada T., Tomimura Y., Magara K., Ishihara M. and Hosoya S. : J. Wood Sci. 45 (5), 417-424（1999）

6) Jiang Z. -H., Lierop B. V. and Berry R. : Tappi J. 83 (1) 167-175 (2000)

7) TAPPI TEST METHODS : “T $236 \mathrm{~cm}-85$ ”, TAPPI PRESS, 1996

8) Yokoyama T., Ohi H. and Nakamata K. : JAPAN TAPPI J. 58 (6) 79-85 (2004)

9) Telman A., Harjunpää V., Tenkanen M., Buchert J., Hausalo T., Drakenberg T. and Vuorinen T. : Carbohydrate Res. 272, 55-71 (1995)

10) Telman A., Hausalo T., Tenkanen M. and Vuorinen T. : Carbohydrate Res. 280 (2), 197-208（1996）
11) Vuorinen T., Renkanen A., Fagerström P., Buchert J. and Tenkanen M. : 1996 Int. Pulp Bleaching Conf., Conf. Proceedings. TAPPI, Washington, D. C., Apr. 14 $-18,1996$, p 43-51

12) Takahashi S., Nakagawa A., Jin G. and Ohi H. : Proceedings of The $52^{\text {nd }}$ Lignin Symposium, Utsunomiya, Japan, November 14-15, 2007, 110-113

13) Kleppe P. J. : Tappi J. 53 (1), 35-47 (1970)

14) Marcoccia B., Stromberg B., Progh I. R. and Kawakami C. : Japan Tappi J. 52 (4) 458-468（1998）

15) Luthe C., Berry R. M., Radiotis T. and Nadeau L. : J. Pulp Paper Sci. 29 (11), 371-376 (2003)

16) Easty D. B. and Malcolm E. W. : Tappi J. 65 (12) 7880 (1982)

17) Ohi H., Yokoyama T., Nakamata K., Suzumi R. and Sato T. : JAPAN TAPPI J. 58 (10) 1446-1452（2004）

18) Yokoyama T. and Ohi H. : JAPAN TAPPI J. 58 (12) 1742-1751 (2004)

19) Meller A. : Holzforschung 19 (4) 118-124 (1965)

20) Kleppe P. J. : Tappi J. 58 (8) 172-176 (1975)

21) Kleppe P. J. : Paperi Puu, 63 (4) 204-210（1981）

22) Vaaler D., Eriksen O., Ribe E. and Moe S. : Seventh European Workshop on Lignocellulostics and Pulp, Conf. Proceedings. Turku, Finland, August 2629, 2002, 265-268

23) Li J. and Gellerstedt G. : Carbohydrate Res. 302, 213218 (1997)

24) Granström A., Eriksson T. and Gellerstedt G. : Nord. Pulp Paper Res. J. 16 (1) 18-23 (2001)

25) Kawae A. and Uchida Y. : Appita J. 58 (5) 378-381. (2005)

26) Gustavsson C. and Wafa AI-Dajani W. : Nord. Pulp Paper Res. J. 15 (2) 160-167 (2000)

27) Chai X. -S., Yoon S., -H., Zhu J. Y. and Li J. : J. Pulp Paper Sci. 27 (12) 407-411 (2001) 